Boston University School of Law

Scholarly Commons at Boston University School of Law

Faculty Scholarship

1998

The Shadowlands: Secrets, Lies, and Assisted Reproduction

George J. Annas

Follow this and additional works at: https://scholarship.law.bu.edu/faculty_scholarship

Part of the Health Law and Policy Commons 
Legal Issues in Medicine

\section{The Shadowlands - Secrets, Lies, ANd Assisted Reproduction}

\author{
George J. AnNAS, J.D., M.P.H.
}

\section{A}

MERICANS love babies and technology, and most Americans applaud the ability of the new assisted-reproduction techniques to help infertile couples have children. But these techniques have also given birth to a wide variety of new legal issues, including questions about the identity of the mother and father of the child, the enforcement of preconception contracts, the elements of informed consent, and the disposition of frozen embryos. After almost 20 years of experience and the growth of infertility clinics into a multibillion-dollar industry, it is time to consider establishing national standards and a federal regulatory scheme. Two recent court cases, one in California and the other in New York, and the report of the New York State Task Force on Life and the Law suggest that existing practices are inadequate to protect the interests of clinic patients and their children.

\section{PARENTLESS IN CALIFORNIA}

The California case involved Luanne and John Buzzanca, who used in vitro fertilization (IVF) with donor eggs and donor sperm. ${ }^{1}$ The embryos were subsequently implanted in a genetically unrelated woman (the "surrogate" mother) for gestation and birth. The Buzzancas intended to rear the resulting child as their own. Before the child, Jaycee, was born, the couple separated and John wanted to have nothing to do with the child.

At a trial held to determine the legal parents of Jaycee, the identity of the genetic parents remained secret, and the gestational mother disclaimed any interest in the child. Because neither John nor Luanne was genetically or biologically related to Jaycee, the judge concluded that Jaycee was parentless. In my view, the conclusion - that a child with six potential parents (assuming the gestational mother was married) was legally parentless - was untenable. ${ }^{2}$ This decision was properly reversed on appeal.

The appeals court decided that because, under California law, a husband who consents to his wife's artificial insemination becomes the legal father of the child, "a husband and wife [should be] deemed

From the Health Law Department, Boston University School of Public Health, Boston.

(C) 1998, Massachusetts Medical Society. the lawful parents of a child after a surrogate bears a biologically unrelated child on their behalf . . . [since] in each instance a child is procreated because a medical procedure was initiated and consented to by intended parents." Thus, the court concluded that Luanne and John were Jaycee's legal parents.

To make sure no one missed the analogy, the court expanded on it, stating that gestational surrogacy and artificial insemination are "exactly analogous in this crucial respect: both contemplate the procreation of a child by the consent to a medical procedure of someone who intends to raise the child but who otherwise does not have any biological tie." The court did not like the idea of people who are responsible for the creation of a child "turning around and disclaiming any responsibility after the child is born." Since the court believed that John "caused" the birth of Jaycee simply by signing a contract, the court had no problem concluding that the same logic that made him the legal father made $\mathrm{Lu}^{-}$ anne (his wife at the time the contract with the surrogate mother was signed) the legal mother, since she agreed to the "procreative project" at the start.

The appeals court nonetheless concluded that it would be preferable for the legislature to set the rules in this arena: "We still believe it is the Legislature ... which is the more desirable forum for lawmaking." And at the end of its opinion, the court tried to reassure John, now the legal father, that things might work out for the best. The court conceded that John may have agreed to the surrogate-mother arrangement simply "as an accommodation to allow Luanne to surmount a formality" but observed that "human relationships are not static; things done merely to help one individual overcome a perceived legal obstacle sometimes become much more meaningful." ${ }^{1}$ Of course, there is no legal basis for such musings, and the court resorted to citing literature to bolster its opinion. It referred approvingly to Shadowlands, a play about the life of C.S. Lewis and his marriage to an American citizen, Joy Gresham, which was arranged so that she could stay in England. ${ }^{3}$ Just as a deeper relationship developed between Lewis and Gresham, the court seemed to be saying, a deeper relationship may develop between John and Jaycee, if not between John and his former wife, Luanne.

\section{NEW YORK'S FROZEN EMBRYOS}

The New York case involved an attempt by Maureen Kass and her husband, Steven, to have a baby by means of IVF. ${ }^{4}$ Maureen had previously undergone five egg-retrieval procedures and nine embryo transfers; none resulted in a live birth. Before the 10th and final attempt, for which Maureen's sister agreed to try to carry the couple's embryos, the couple signed four consent forms. Included in an addendum to one of the forms was the statement that if 
the couple "no longer wish to initiate a pregnancy or are unable to make a decision regarding the disposition of our stored, frozen pre-zygotes . . . [they] may be disposed of by the IVF program for approved research investigation as determined by the IVF program."4 Maureen's sister failed to become pregnant, and the couple subsequently decided to divorce.

Maureen then sought sole custody of the remaining frozen embryos so that she could undergo another implantation procedure. Steven opposed her request. The trial court granted custody of the embryos to Maureen, but an appeals court reversed this ruling in a split decision; the majority of the judges held that the provision that the embryos be turned over for research should be enforced. ${ }^{5}$ This decision was appealed to New York's highest court, the Court of Appeals, which affirmed the decision that the couple's prior agreement, including the provision in question, should be enforced. The basic reason for this conclusion was that "advance directives, subject to mutual change of mind that must be jointly expressed, both minimize misunderstandings and maximize procreative liberty by reserving to the progenitors the authority to make what is in the first instance a quintessentially personal, private decision." a document evidences informed, mutual consent, the court ruled, it should be honored by the courts. In the court's concluding words:

As they embarked on the IVF program, appellant and respondent - "husband" and "wife," signing as such clearly contemplated the fulfillment of a life dream of having a child during their marriage. The consents they signed provided for other contingencies, most especially that in the present circumstances the pre-zygotes would be donated to the IVF program for approved research purposes. These parties have clearly manifested their intention, the law will honor it. ${ }^{4}$

\section{SIMILARITIES AND LESSONS}

These cases illustrate the two primary ways in which clinics and courts have tried to avoid the new legal issues raised by assisted-reproduction techniques: application of the sperm-donor model of secrecy to all aspects of infertility treatment, and dependence on contracts. Both clinics and courts like contracts, because they seem to put private, procreation-related decision making in the hands of the married couple and permit the courts simply to interpret and enforce voluntary agreements. The problem, however, is that much more than contract law is at stake in these cases. The courts are not simply affirming the contents of a contract but are implicitly making profound and wide-ranging decisions about the status of embryos, the interests of children, and the identification and responsibility of their parents. The inadequacy of contract analysis in this area can be seen by the fact that no court has ever forced any person to fulfill the terms of a surrogate-mother contract, a custody contract, or a marriage contract by requiring that the parties be bound by the contractual terms regardless of their current wishes or the best interests of the children involved. ${ }^{6,7}$

The California appeals court seemed to be simply honoring a surrogate-mother contract made before Jaycee's conception. In fact, however, the court was implicitly holding that the determination of motherhood would be governed by the same rules that the legislature has adopted to determine fatherhood in the case of sperm donation. The court seemed to see this as a neutral approach with respect to sex, but applying the model of sperm donation to women devalues both pregnancy and childbirth, since according to the court's analysis, not only the genetic mother (who as a donor of the egg used in the "procreative project" could arguably be considered analogous to a sperm donor, even though donating eggs is much more painful and risky than donating sperm) but also the gestational mother is eliminated from consideration as the child's mother. Likewise, the court decided that because sperm donors have historically had their identities kept secret even from the children conceived as a result of their "donations," keeping the identities of both the egg donor and the gestational mother a secret is appropriate.

Because both the primacy of the contract and the value of secrecy can be disputed, it is not surprising that the court concluded its opinion with a reference to Shadowlands rather than to the law. Shadowlands is a strong play, and its main character, C.S. Lewis, was a great writer, but to cite the play as a basis for the proposition that "a deeper relationship" may develop between a man and a woman than that contemplated at the time of a marriage of convenience misses the point not only of the play itself (which is about the meaning of suffering) but also of the case itself (since the marriage had already ended in divorce). For Lewis, the real world was no more than "the shadowlands" from which we will emerge, like Plato's cave-dwelling prisoners, into the afterlife, where we will finally see reality clearly. ${ }^{9}$

The California court's most important insight was that courts have an extremely difficult time making meaningful public policy in the realm of assisted reproduction because they are limited to deciding individual disputes after the fact, and that the legislature, which ideally can foresee and prevent disputes, is therefore the preferred law-making body in this area. The New York Court of Appeals did not do much better. The judges seemed to be especially proud of themselves for affirming the contract (consent form) the couple had signed (even though it was a technical, boilerplate form that was difficult to understand). But in affirming the contract, the court failed to examine the implications of its terms for public policy. For example, although informed con- 
sent is necessary for research involving human embryos, the gamete donors retain the right to withdraw their consent at any time. To the extent that the consent of both parties is necessary for valid consent to research (and this is what the consent form required), the withdrawal of consent by either party should mean that the research cannot proceed.

It may be that the New York court missed this point because it adopted the language of the consent form, with its meaningless term "pre-zygotes" (instead of embryos). Other clinics have used the euphemistic term "pre-embryos," but virtually everyone has now abandoned the prefix because the most meaningful distinction is between extracorporeal embryos (over which male and female gamete providers have equal say) and implanted embryos (over which the pregnant woman has the ultimate decision-making authority). The terms used often determine the outcome. It is evidence of the court's confusion that even though the court said it was adopting the terms used in the consent form, in the opinion, three different terms are used for the same entities: embryos, fertilized eggs, and pre-zygotes.

Finally, to the extent that the New York court was correct in concluding that the couple embarked on IVF and signed the consent form contemplating "the fulfillment of a life dream of having a child during their marriage," their divorce put an end to this dream and radically altered their circumstances. Divorce would seem to be a sufficient change to call into question the embryo agreement, like the marriage agreement itself, and to provide each former spouse with the opportunity to revoke it.

\section{CASE LAW OR LEGISLATION?}

These courts arguably did as well as they could, and reliance on prior contracts as a way to resolve controversies in assisted reproduction has also been espoused by leading legal commentators. ${ }^{10}$ Nonetheless, the California court is correct in asking that the legislature establish rules in this arena. The court's opinion, for example, gives no guidance on what should happen if the gestational mother or the egg donor changes her mind and wants to be designated the legal mother with the rights and responsibilities to rear Jaycee. Must obstetricians and hospitals locate and interpret contracts to determine who a child's legal mother is at the time of birth? Do commerce, money, and contracts really have more to say about motherhood than pregnancy and childbirth? If we consider the best interests of children more important than the best interests of commerce, children will be best protected by a universal rule that the woman who gives birth to the child is the child's legal mother - with, among other things, the right to make treatment decisions on behalf of the child and the responsibility to care for the child. ${ }^{11} \mathrm{I}$ believe this not because it is the traditional or natural rule but because the gestational mother is the only one of the three potential mothers who must be present at the child's birth and available to make decisions on behalf of the child. She is also the only one of the three potential mothers who has a personal relationship with the child. Decisions about treatment and care of the child must often be made immediately; the issues of long-term care, relinquishment of parental rights, and adoption can be dealt with later.

Similarly, the New York court acknowledged in its opinion that the New York State Task Force on Life and the Law recently "issued a comprehensive report . . . together with recommendations for regulation ... addressing a wide range of relevant subjects." ${ }^{4}$ The court, however, took no position on the recommendations themselves, and it is unclear from the opinion whether the judges actually had an opportunity to read the report (which was released only a week before the court's opinion was published). ${ }^{12,13}$

\section{THE NEW YORK STATE TASK FORCE}

This year the New York State Task Force issued the first comprehensive legislative report on assisted reproduction in the United States. ${ }^{12}$ Similar reports were issued in the United Kingdom, ${ }^{14}$ Australia, ${ }^{15}$ and Ontario ${ }^{16}$ more than a decade ago, and Canada issued a national report in $1993 .{ }^{17}$ The United States has been slow to regulate the assisted-reproduction industry because of continuing controversies over abortion and embryo research, as well as our basic belief that, to a large extent, decisions about assisted reproduction should be left to couples and their physicians. ${ }^{18,19}$ But certain aspects of these decisions have such a strong impact on matters of concern to society - such as child support and care, decisions about medical treatment and education for children, the social identity and responsibility of parents, basic informed-consent requirements, and record keeping that they require public scrutiny and regulation. ${ }^{12-17}$

The assisted-reproduction industry caters to the wishes of adults, and their wishes consistently trump the interests of children. The abortion model of private decision making has been used to resist the regulation of assisted reproduction (even though what is sought is the birth of a child, not the termination of a pregnancy), and the sperm-donor model has consistently been applied to egg donation, pregnancy, and childbirth, even though none of them are equivalent. ${ }^{2,6,7}$ Perhaps the most disturbing aspect of the application of the sperm-donor model to virtually all assisted-reproduction techniques is the insistence on secrecy - to such an extent that records about sperm donors and their donations are routinely kept from the children conceived as a result of the donations, who are intentionally and systematically deprived of knowledge of their genetic parents. ${ }^{8,17,20}$ 
Secrecy has been the norm in donor insemination since its introduction. ${ }^{8,12}$ Worse, parents may be counseled to lie to their children about their genetic heritage, even though family secrets can adversely affect the entire family. ${ }^{8,12,21-23}$

The New York State Task Force recommended approximately 60 changes in professional standards and guidelines, 30 changes in state regulation of gamete banks, and 11 new state laws. ${ }^{12}$ It is not necessary to agree with all these recommendations to appreciate the number of areas that may require regulation. The task force was concerned, for example, about the growing number of multiple pregnancies resulting from the use of fertility drugs and the implantation of multiple embryos. These practices can result in multiple births, which are associated with increased risks of prematurity and low birth weight, or in fetal reduction (selective abortion of some of the fetuses). The task force ultimately could not agree on how to regulate multiple pregnancies. A private multidisciplinary group has recently recommended federal legislation to limit the number of implanted embryos per cycle to four. ${ }^{24}$ The task force was also concerned about the lack of uniform standards for record keeping, consent procedures and forms, counseling, screening, reporting of success rates, egg donation, and embryo research.

The task force's most important decision was to adopt a child-centered perspective that takes seriously the protection of the interests of the children born as a result of assisted-reproduction techniques - for example, by identifying the children's legal parents and requiring clinics to keep records on behalf of the children. The most important specific recommendation was that "New York law should clearly provide that the woman who gives birth to the child is the child's legal mother, even if the child was not conceived with the woman's egg."12 If this rule had been in effect in California, the dispute there would not have occurred, since the gestational mother and her husband (if she was married) or the genetic father (if she was single) would have been Jaycee's legal parents, and they would have had to relinquish their parental rights to give her up for adoption. The task force's recommendations could also have resolved the dispute in the New York case, since it recommended that use of frozen embryos always require the agreement of both gamete providers, thus giving each veto power. ${ }^{12,25}$

\section{THE FEDERAL ROLE}

More important than the rules proposed by the task force is its attempt to move the regulation of assisted reproduction out of the shadowlands of private clinics and the public realm of private disputes (the courts) into the light of public democratic lawmaking. Both the regulation of medicine and family relations have historically been dealt with under state law, not federal law. It has seemed reasonable for the states to handle these issues themselves and for the law to develop on a state-by-state basis. Nonetheless, to the extent that assisted reproduction has become big business and to the extent that it is more accurately characterized as a commercial enterprise than as a medical or family-related enterprise, federal regulation of at least its interstate commercial aspects deserves consideration.

Other countries that have developed uniform standards for the infertility industry have appointed a committee or commission to study the issues and make legislative recommendations. ${ }^{14-17}$ It seems likely that if we want to consider establishing uniform commercial standards in this country, a similar panel will have to be appointed by the president. The Advisory Committee on Human Radiation Experiments provides the best recent model, since it was given a specific charge, had an adequate budget, and received the cooperation of the relevant federal agencies. ${ }^{26}$

The states will, of course, continue to have jurisdiction over determining motherhood, fatherhood, child custody, and related issues of family law. But national standards of commerce could be developed for assisted reproduction, as they have for organ transplantation. A national advisory committee on the new reproductive techniques should consider uniform national rules that address the following issues: the content of informed consent in terms of the risks to parents and children; standard screening and recordkeeping requirements for egg and sperm donation; the ability of children born as a result of assisted reproduction to learn the identity of their genetic and gestational parents; research on human embryos; time limits on the storage of human embryos; the use of gametes from deceased persons to produce children; and the addition of eggs and embryos (and possibly sperm as well) to the list of human tissues that cannot be purchased or sold in the United States.

C.S. Lewis, who also wrote children's books, believed that a "bad way" to write for children is to do so as a special category of "giving the public what it wants." ${ }^{28}$ Likewise, a bad way to protect the children who have been conceived and born with the assistance of the new reproductive techniques is simply to provide the adults involved with what they want. In late 1997, President Bill Clinton signed a federal law designed to shift the emphasis in adoption practices from the rights of the biologic parents to the welfare of the children. ${ }^{28}$ The assisted-reproduction industry should move in this direction as well. As with adoption, however, it will probably take federal action to move children to the center of consideration in the infertility business.

\section{REFERENCES}

1. Buzzanca v. Buzzanca, 61 Cal. App. 4th 1410 (1998)

2. Annas GJ. Fertility clinics hardly letter perfect. Boston Globe. November 30, 1997:Dl. 
3. Nicholson W. Shadowlands. New York: Penguin Books, 1991.

4. Kass v. Kass, 91 N.Y. 2d 554 (1998).

5. Kass v. Kass, 235 A.D. 2 d 150, 663 N.Y.S 2d 581 (App. Div. 2d Dept. 1997).

6. Radin MJ. Contested commodities. Cambridge, Mass.: Harvard University Press, 1996

7. Annas GJ. Standard of care: the law of American bioethics. New York: Oxford University Press, 1993:61-84.

8. Idem. Fathers anonymous: beyond the best interests of the sperm donor. Family Law Q 1980;14:1-13.

9. Lewis CS. The last battle. New York: Harper Collins, 1994 (originally published in 1956).

10. Robertson JA. Children of choice. Princeton, N.J.: Princeton University Press, 1994

11. Elias S, Annas GJ. Social policy considerations in noncoital reproduc tion. JAMA 1986;255:62-8.

12. The assisted reproductive technologies: analysis and recommendations for public policy. New York: New York State Task Force on Life and the Law, 1998.

13. Altman L. Health panel seeks sweeping changes in fertility therapy. New York Times. April 29, 1998:Al.

14. Report of the committee of inquiry into human fertilization and embryology. London: Department of Health and Social Security, 1984. 15. Report on the disposition of embryos produced by in vitro fertilization. Melbourne, Australia: Committee to Consider the Social, Ethical and Legal Issues Arising from In Vitro Fertilization, 1984

16. Ontario Law Reform Commission. Report on human artificial repro duction and related matters. Toronto: Ministry of the Attorney General, 1985.
17. Royal Commission on New Reproductive Technologies. Proceed with caution. Ottawa, Canada: Minister Gov. Services, 1993.

18. House of Representatives. Hearings on the extracorporeal embryo be fore the Investigations and Oversight Subcommittee of the Science and Technology Committee, August 8-9, 1984. Washington, D.C.: Government Printing Office, 1984

19. Annas GJ, Caplan A, Elias $S$. The politics of human-embryo research — avoiding ethical gridlock. N Engl J Med 1996;334:1329-32.

20. Ethics Committee, American Fertility Society. Ethical considerations of assisted reproductive technologies. Fertil Steril 1994;62:Suppl 1:1S-125S.

21. Baran A, Pannor R. Lethal secrets: the shocking consequences and unsolved problems of artificial insemination. New York: Warner Books, 1989 22. Leiblum SR, Hamkins SE. To tell or not to tell: attitudes of reproductive endocrinologists concerning disclosure to offspring of conception via assisted insemination by donor. J Psychosom Obstet Gynaecol 1992;13: 267-75

23. Nachtigall RD, Tschann JM, Quiroga SS, Pitcher L, Becker G. Stigma, disclosure, and family functioning among parents of children conceived through donor insemination. Fertil Steril 1997;68:83-9.

24. ISLAT Working Group. ART into science: regulation of fertility techniques. Science 1998;281:651-2.

25. Moskowitz EH. Some things don't belong in contracts. National Law Journal. June 8, 1998:A25.

26. Advisory Committee on Human Radiation Experiments. Final report. Washington, D.C.: Government Printing Office, 1995.

27. Lewis CS. Of other worlds: essays and stories. New York: Harcourt Brace Jovanovich, 1966:22-34.

28. Seelye KQ. Clinton to approve sweeping shift in adoption. New York Times. November 17, 1997:A20.

\section{FULL TEXT OF ALL JOURNAL ARTICLES ON THE WORLD WIDE WEB}

Access to the complete text of the Journal on the Internet is free to all subscribers. To use this Web site, subscribers should go to the Journal's home page (www.nejm.org) and register by entering their names and subscriber numbers as they appear on their mailing labels. After this one-time registration, subscribers can use their passwords to $\log$ on for electronic access to the entire Journal from any computer that is connected to the Internet. Features include a library of all issues since January 1993, a full-text search capacity, a personal archive for saving articles and search results of interest, and free software for downloading articles so they can be printed in a format that is virtually identical to that of the typeset pages. 